Proc. Estonian Acad. Sci. Geol., 1997, 46, 4, 155-168

\title{
CORRELATION OF SOME WENLOCK OUTCROP SECTIONS OF GOTLAND WITH THE OHESAARE SECTION OF SAAREMAA, ESTONIA
}

\author{
Viiu NESTOR and Rein EINASTO
}

Institute of Geology, Estonia pst. 7, EE-0001 Tallinn, Estonia; e-mail: vnestor@gi.ee, einasto@gi.ee

Received 28 January 1997, in revised form 1 October 1997

\begin{abstract}
In the Högklint Beds of the Vattenfallet and Nygårdsbecken sections sediments of restricted and open shelf and shoal environments are exposed. According to the chitinozoan data, not any of the boundaries between the subunits of the Högklint Beds corresponds exactly to the distinct boundary between the Mustjala and Ninase members in the sections of Saaremaa. In the lowermost part of the Slitebrottet 2 quarry open shelf nodular limestones with a few sharp hardgrounds, marking boundaries of field-scale (meso)cycles, are present. The succession of chitinozoan species indicates that the studied section of Slitebrottet 2 corresponds to the upper part of the Cingulochitina cingulata Biozone and the lower part of the Eisenackitina lagena Biozone in the lower half of the Jamaja Formation in the Ohesaare section of Saaremaa.
\end{abstract}

Key words: Silurian, Wenlock, Chitinozoa, correlation, cyclicity, Gotland, Sweden, Ohesaare, Estonia.

\section{INTRODUCTION}

Lithology, fauna, and stratigraphy of the islands of Gotland and Saaremaa lying close to each other have been carefully investigated for over a century. Still, there are some unsolved problems, including detailed correlation of certain stratigraphical intervals. One problem is dia- or synchronism of the well-known lithostratigraphic boundary between the underlying open-shelf marls and the resting reef-complex of the shoal belt, i.e., the boundary between the Upper Visby and Högklint beds on Gotland and Mustjala and Ninase members of the Jaani Formation on Saaremaa.

The conodont-based correlation between the Wenlock sequence of Gotland and outcrop area of Saaremaa was recently discussed by Jeppsson et al. (1994). In the present paper we try to correlate some outcrops of Gotland with the 
Ohesaare core section (Figs. 1-3), which is mostly represented by marls and mudstones and has been treated in the last years as the reference section for the succession of Wenlock Chitinozoa in the East Baltic area (Nestor, 1994).

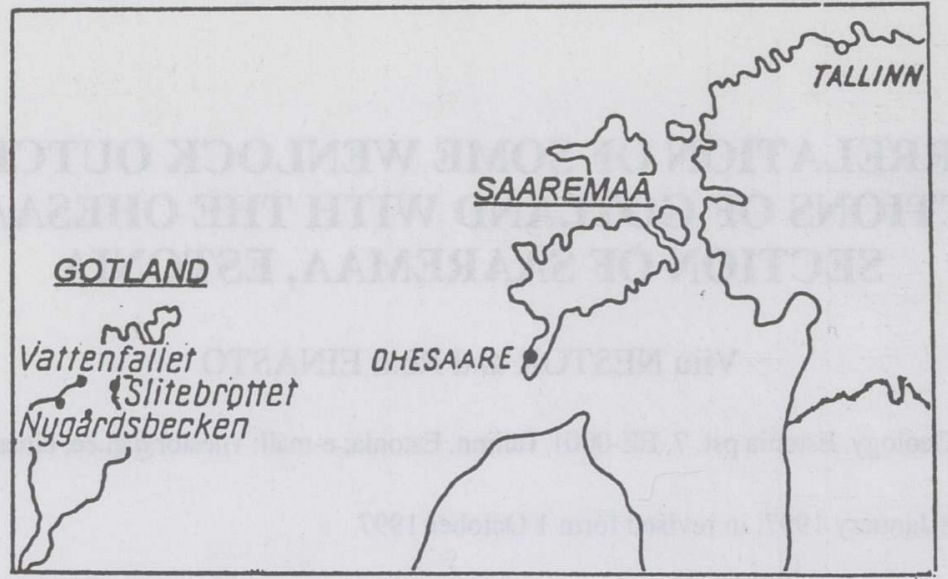

Fig. 1. Location of the studied sections.

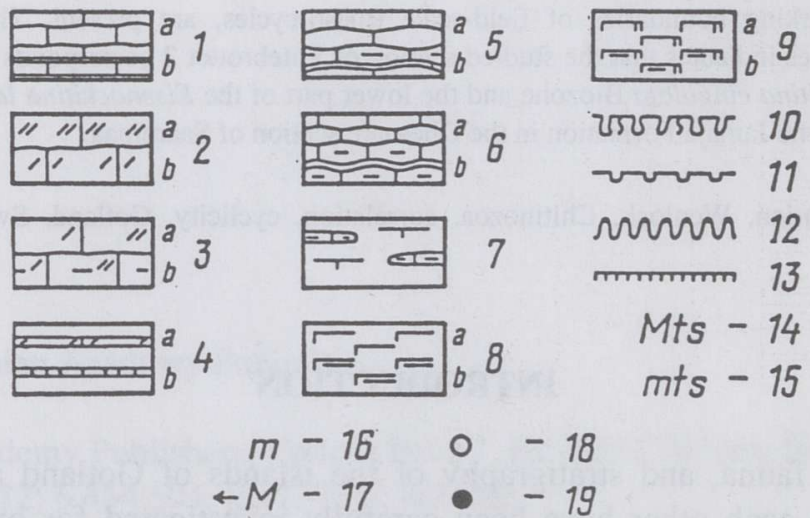

Fig. 2. Key to Figs. 3-6. 1, limestone: $a$, pure, $b$, with marlstone interbeds; 2, skeletal grainstone: $a$, coarse-grained, $b$, fine-grained; 3 , wackestone: $a$, pure, $b$, argillaceous; 4 , interbeds: $a$, skeletal grainstone, $b$, pelletal grainstone; 5 , nodular limestone: $a$, pure, $b$, argillaceous with marlstone interbeds; 6 , fine nodular limestone: $a$, pure, $b$, argillaceous with marlstone interbeds; 7 , marlstone with limestone nodules; 8 , marlstone: $a$, calcareous, $b$, argillaceous; 9 , dolomitic marlstone: $a$, pure, $b$, argillaceous; 10 , hardground with deep pockets and burrows; 11 , hardground; 12 , strongly burrowed pyritized hardground; 13, metabentonite layer (MB); 14, mesocyclite; 15, microcyclite; 16 , thin marlstone interlayer; 17 , sample of chitinozoans; 18 , occurrence of species; 19 , abundant occurrence of species. 


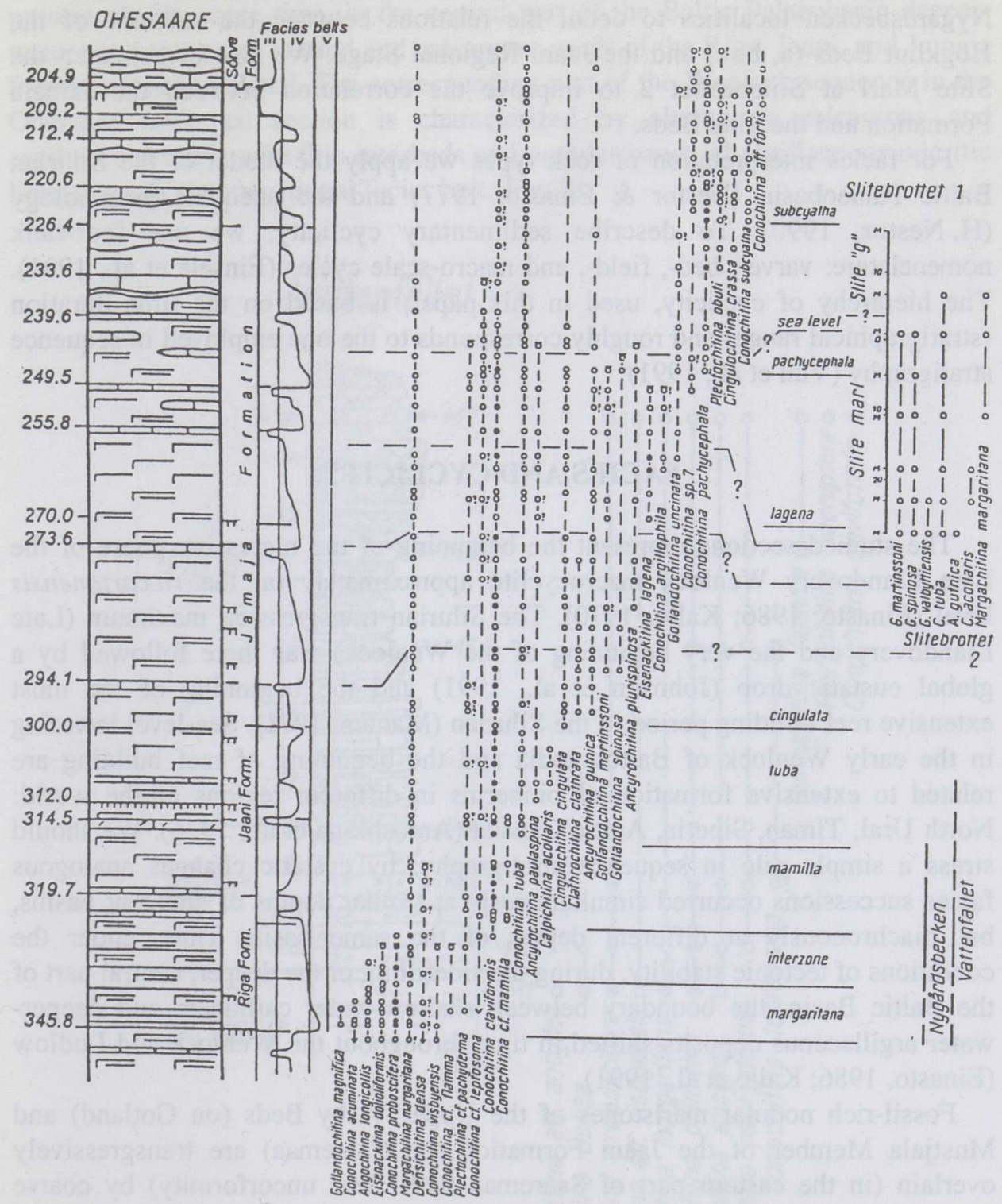

Fig. 3. Lithological log, facies curve, ranges of selected chitinozoan species, and succession of chitinozoan biozones in the lower and middle Wenlock of the Ohesaare core. Chitinozoan ranges at Slitebrottet 1 according to Laufeld, 1974. Facies belts: III, open shelf; IV, transitional; V, depression. Stratigraphic position of the Vattenfallet and Nygårdsbecken sections and Slitebrottet quarries. For key see Fig. 2. 
During a field trip to Gotland in summer 1994 we studied the Vattenfallet and Nygårdsbecken localities to detail the relations between the subunits of the Högklint Beds ( $a, b, c)$ and the Jaani Regional Stage. We also investigated the Slite Marl at Slitebrottet 2 to improve the correlation between the Jamaja Formation and the Slite Beds.

For facies interpretation of rock types we apply the model of the Silurian Baltic Palaeobasin (Nestor \& Einasto, 1977) and the adequate terminology (H. Nestor, 1990). To describe sedimentary cyclicity, we use four-rank nomenclature: varve-, bed-, field-, and macro-scale cycles (Einsele et al., 1991). The hierarchy of cyclicity, used in this paper, is based on the time duration (stratigraphical range) and roughly corresponds to the one employed in sequence stratigraphy (Vail et al., 1991).

\section{FACIES AND CYCLICITY}

The studied sections represent the beginning of the regressive phase of the Late Llandovery-Wenlock macrocyclite approximately on the riccartonensis level (Einasto, 1986; Kaljo, 1970). The Silurian transgression maximum (Late Llandovery and the very beginning of the Wenlock) was there followed by a global eustatic drop (Johnson et al., 1991) and the beginning of the most extensive reef building period in the Silurian (Manten, 1971). Sea-level lowering in the early Wenlock of Baltoscandia and the beginning of reef building are related to extensive formation of bioherms in different regions of the world: North Ural, Timan, Siberia, Arctic Canada (Antoshkina et al., 1976). We should stress a simple rule in sequence stratigraphy: by eustatic changes analogous facies successions occurred simultaneously at similar depths of different basins, but diachronously at different depths of the same basin. Thus, under the conditions of tectonic stability, during the sidefilling of the deeper, central part of the Baltic Basin, the boundary between shallow-water carbonate and deeperwater argillaceous deposits shifted in time throughout the Wenlock and Ludlow (Einasto, 1986; Kaljo et al., 1991).

Fossil-rich nodular marlstones of the Upper Visby Beds (on Gotland) and Mustjala Member of the Jaani Formation (on Saaremaa) are transgressively overlain (in the eastern part of Saaremaa with clear uncorformity) by coarse skeletal grainstones of the Högklint "a" and Ninase Member, respectively. In the Högklint Beds of the Vattenfallet (Fig. 4) and Nygårdsbecken (Fig. 5) sections argillaceous wackestones of restricted and open shelf environments (in the middle part of the field-scale cycle) and well-sorted skeletal grainstones of near-shore shoals (in the lower- and uppermost parts of the field-scale cycle) are exposed, representing adjacent facies to a reef-belt. At Slitebrottet 2 (Fig. 6) there occur open shelf nodular limestones with thin $(5-10 \mathrm{~cm})$ grainstone interlayers of graded bedding (probably tempestites). Only some sharp pyritized hardgrounds, 
marking boundaries of bed- and field-scale (micro- and meso)cycles (Fig. 6), are present. At the same time, in the central part of the Baltic Palaeobasin deeperwater conditions still existed and calcareous muds of the Riga, Jaani, and Jamaja formations accumulated. The corresponding part of the Wenlock sequence in the Ohesaare reference section is characterized by alternating calcareous and argillaceous marls with thin interbeds and nodular bands of argillaceous micritic limestones of the transitional facies belt (Fig. 3).

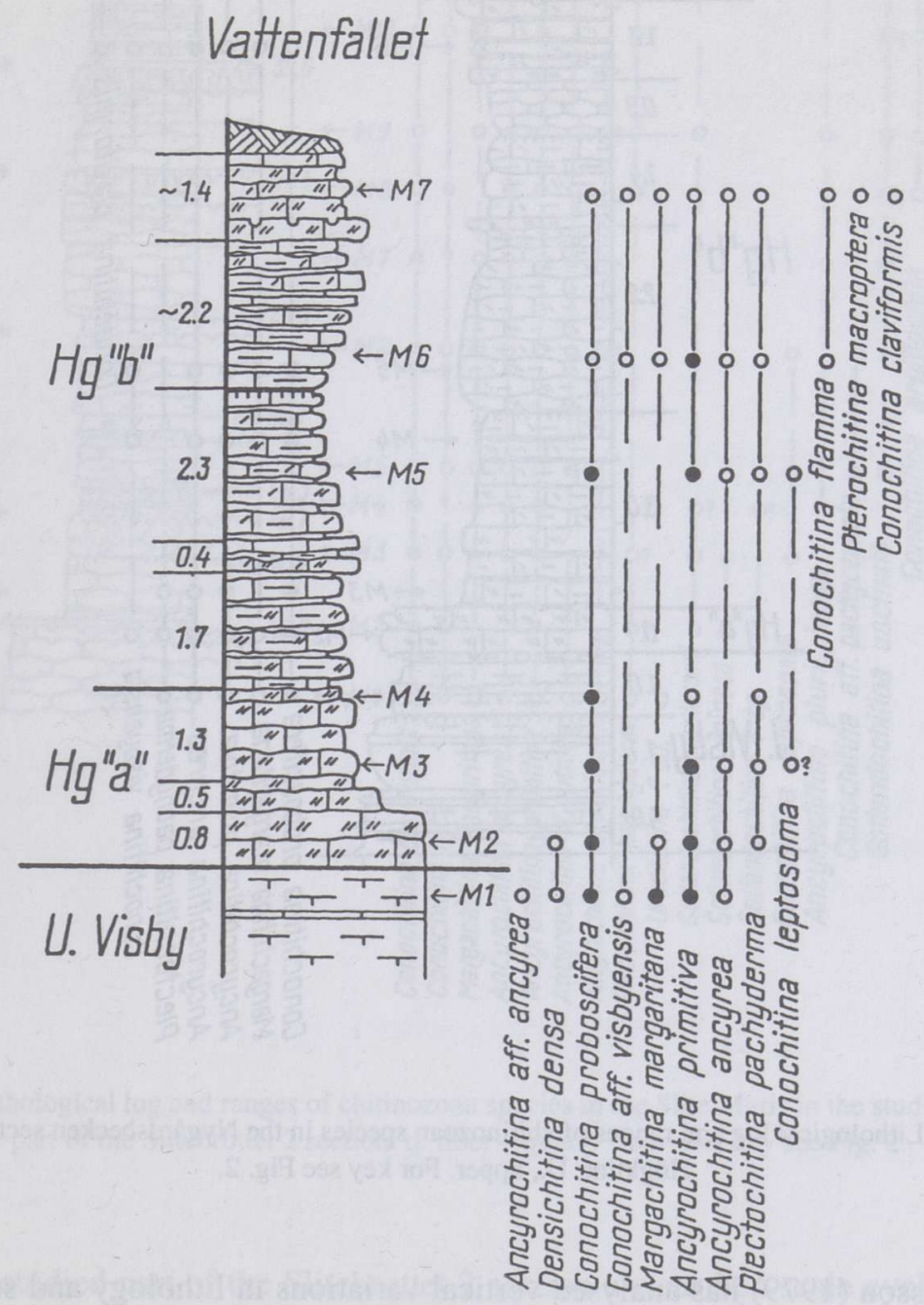

Fig. 4. Lithological log and ranges of chitinozoan species in the Vattenfallet section. Hg, Högklint; U., upper. For key see Fig. 2. 


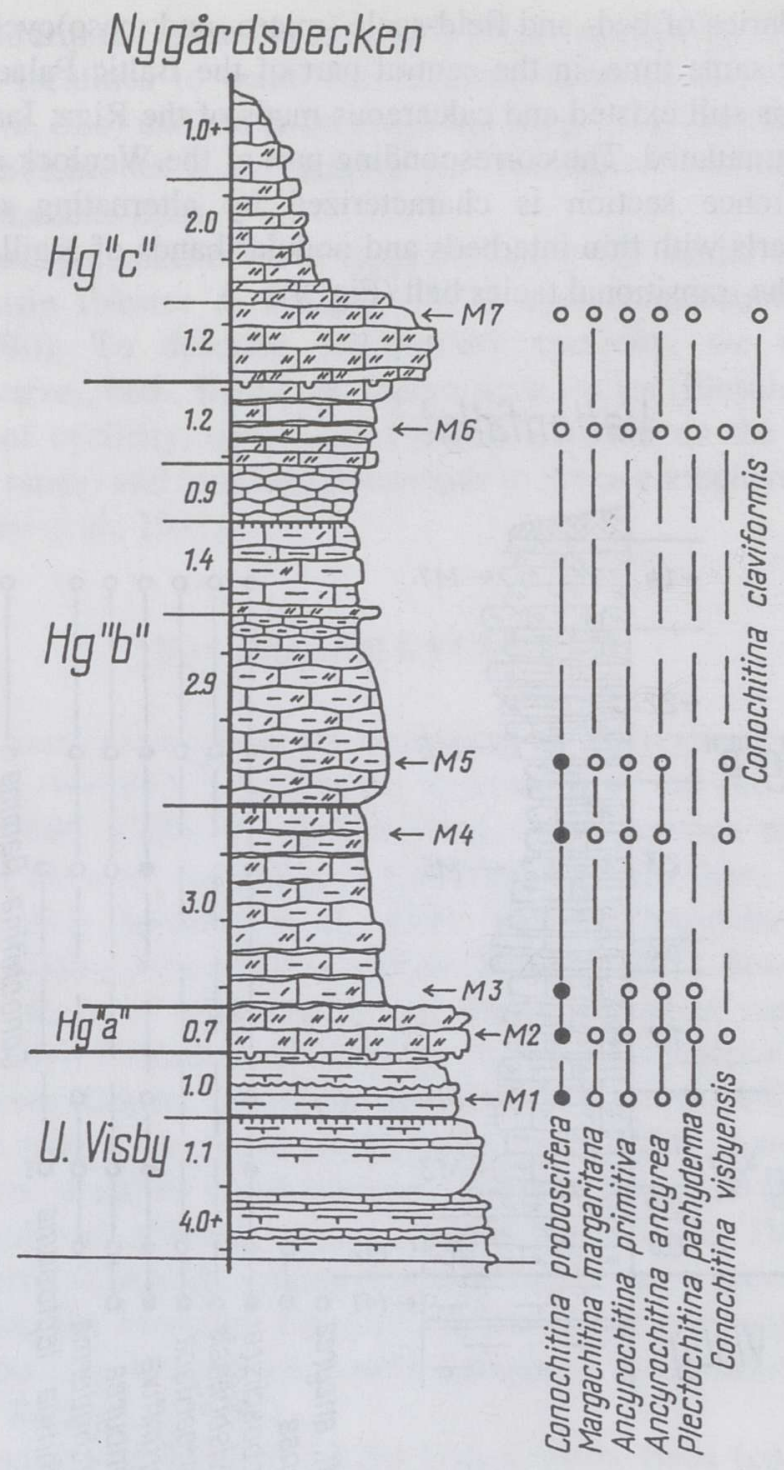

Fig. 5. Lithological log and ranges of chitinozoan species in the Nygårdsbecken section. $\mathrm{Hg}$, Högklint; U., upper. For key see Fig. 2.

Jaanusson (1979) has analysed vertical variations in lithology and subunits of the Högklint Beds in the Vattenfallet section. The Nygårdsbecken section shows a general similarity to Vattenfallet (see Figs. 4, 5): in the upper part of the Nygårdsbecken section, at the beginning of Högklint "c", there occurs a skeletal grainstone interbed $(1.2 \mathrm{~m})$, much alike to Högklint "a". This layer constitutes the basal bed of the next, overlying field-scale (meso)cyclite. 


\section{Slitebrottet 2}

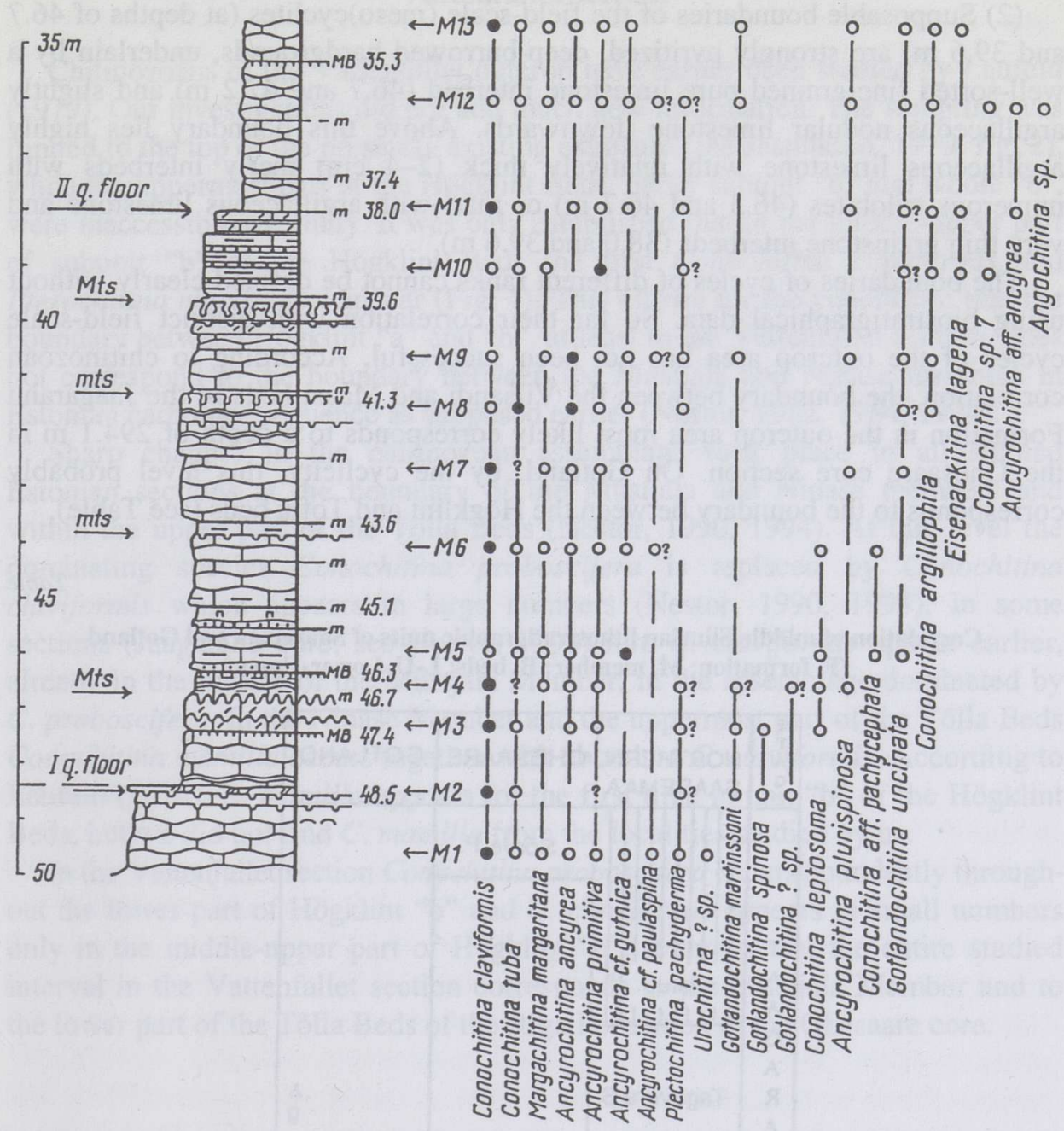

Fig. 6. Lithological log and ranges of chitinozoan species in the Slite Marls in the studied lower part of the Slitebrottet 2 section. q. floor - quarry floor. For key see Fig. 2.

In the studied part of the Slitebrottet 2 section a clear bed-scale cyclicity was visible. On the ground of lithological characteristics we could distinguish two ranks of cyclite boundaries (Fig. 6):

(1) Junctions of the bed-scale (micro)cyclites (at depths of 48.5, 47.2, 45.1, $43.6,41.3$, and $38.0 \mathrm{~m}$ ) are marked only by discontinuity surfaces (hardgrounds) within monotonous nodular limestones, sometimes accompanied by thin interbeds 
of skeletal grainstones with corals and stromatoporoids directly below (47.2 and $45.1 \mathrm{~m}$ - fine-grained, well-sorted) or above ( 48.5 and $43.6 \mathrm{~m}$ - poorly sorted).

(2) Supposable boundaries of the field-scale (meso)cyclites (at depths of 46.7 and $39.6 \mathrm{~m}$ ) are strongly pyritized, deep-burrowed hardgrounds, underlain by a well-sorted fine-grained pure limestone interbed (46.7 and $47.2 \mathrm{~m}$ ) and slightly argillaceous nodular limestone downwards. Above this boundary lies highly argillaceous limestone with relatively thick $(2-4 \mathrm{~cm})$ marly interbeds with numerous trilobites $(46.3$ and $46.7 \mathrm{~m}$ ) or marl with argillaceous limestone and very thin grainstone interbeds ( 38.0 and $39.6 \mathrm{~m}$ ).

The boundaries of cycles of different ranks cannot be defined clearly without using biostratigraphical data. So far their correlation with distinct field-scale cycles of the outcrop area has not been successful. According to chitinozoan correlation, the boundary between the Vilsandi and Maasi beds of the Jaagarahu Formation in the outcrop area most likely corresponds to a depth of $294.1 \mathrm{~m}$ in the Ohesaare core section. On Gotland, by the cyclicity, this level probably corresponds to the boundary between the Högklint and Tofta beds (see Table).

Table

Correlation of middle Silurian lithostratigraphic units of Saaremaa and Gotland (F, formation; M, member; B, beds; L-U, Lower-Upper)

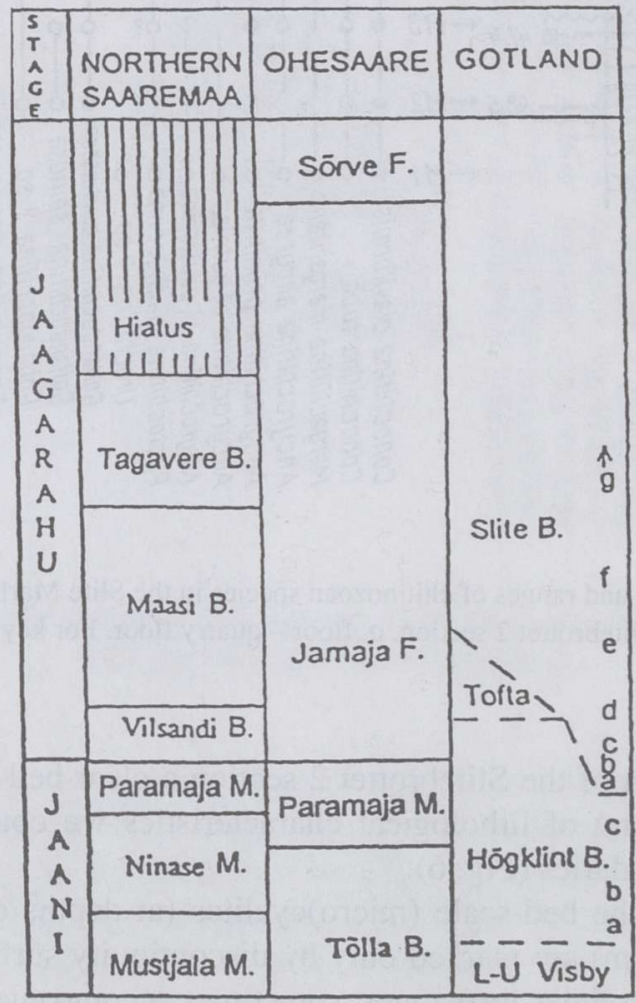




\section{CHITINOZOAN-BASED CORRELATIONS}

\section{Vattenfallet section}

Chitinozoans of the Vattenfallet outcrop have earlier been studied by Laufeld (1979). Our investigations did not add much new information. The sampling was limited to the top of the presently existing exposure (see Jaanusson, 1979, fig. 2), while the uppermost part of the Högklint Beds, partly subunit "b" and whole "c", were inaccessible for study. It was only established that in the middle-upper part of subunit " $b$ " of the Högklint Beds the first Conochitina claviformis and Pterochitina macroptera appear (Fig. 4). This allows for the conclusion that the boundary between Högklint "a" and " $b$ ", at least in the Vattenfallet section, does not correspond to the boundary between the Mustjala and Ninase members in Estonian carbonate sequence as supposed earlier (Nestor, 1982, 1984, 1994).

Sharp changes in the chitinozoan assemblage took place in all studied Estonian sections at the boundary of the Mustjala and Ninase members and within the upper part of the Tõlla Beds (Nestor, 1990, 1994). At this level the dominating species Conochitina proboscifera is replaced by Conochitina claviformis which appears in large numbers (Nestor, 1990, 1994). In some sections (Jaagarahu core; see Nestor, 1993) rare C. claviformis appear earlier, already in the middle of the Mustjala Member, in the assemblage dominated by C. proboscifera. In the Ninase Member and the uppermost part of the Tõlla Beds Conochitina mamilla occurs together with abundant $C$. claviformis. According to Laufeld (1974), C. mamilla appears for the first time in unit "b" of the Högklint Beds, but we did not find C. mamilla from the localities studied by us.

In the Vattenfallet section Conochitina proboscifera occurs abundantly throughout the lower part of Högklint "b" and C. claviformis appears in small numbers only in the middle-upper part of Högklint "b". It shows that the entire studied interval in the Vattenfallet section corresponds to the Mustjala Member and to the lower part of the Tõlla Beds of the Riga Formation in the Ohesaare core.

\section{Nygårdsbecken section}

The section of the Högklint Beds is more completely exposed at the Nygårdsbecken locality (Fig. 5) where we studied the upper part of unit "b" and the lowermost part of unit "c". The species assemblage of chitinozoans in this outcrop is less diverse than that of the Vattenfallet section. Conochitina proboscifera is the dominant species, except the topmost part of the section, where its number decreases considerably. Conochitina claviformis appears for the first time in the upper part of unit "b", but does not gain predominance even in the studied lower part of Högklint " $c$ ".

Thus, no clear evidence permitting the correlation between Högklint " $\mathrm{c}$ " and the Ninase Member was observed in the Nygårdsbecken section. According to 
Jeppsson et al., 1994, the boundary of Högklint subunits "b" and "c" as a lithological one may be diachronous in different places on Gotland, as the lower limit of the range of the conodont Ozarkodina sagitta rhenana crosses this boundary. This may have caused certain confusion also in the chitinozoan correlation between Gotland and Estonia (Nestor, 1984).

\section{Slitebrottet 2 section}

We had a possibility to study only the lowermost part of the new deep quarry of Slitebrottet 2, about $15 \mathrm{~m}$ upwards from the bottom (about $50 \mathrm{~m}$ below sea level) (Fig. 6). This part of the section was not studied by Laufeld (1974), who investigated eight samples taken from the neighbouring Slitebrottet 1 quarry of the Slite Marl, from the interval of $28 \mathrm{~m}$ below sea level and $16 \mathrm{~m}$ above sea level (see Fig. 3).

We took 13 samples at 1-1.5 m intervals from Slitebrottet 2 (Fig. 6). All samples contained numerous chitinozoans. The whole assemblage was similar to the one characterizing the middle or lower-middle part of the Jamaja Formation in the Ohesaare and some other core sections (Ruhnu, Riksu) on West Estonian islands.

Besides the long-ranging species, some stratigraphically more important taxa occur in this part of the sequence. Among them are Ancyrochitina gutnica, appearing for the first time in subunit " $\mathrm{c}$ " of the Slite Beds according to Laufeld (1974), and Gotlandochitina martinssoni and G. spinosa which appear in Slite "f".

Higher up in the Slitebrottet 2 section Ancyrochitina plurispinosa and Eisenackitina lagena make their appearance. A similar succession of the first occurrences of the species is recorded also in the Ohesaare core, at a depth from 282 to $269 \mathrm{~m}$. Although the zonal species Cingulochitina cingulata and Clathrochitina clathrata were not found within this interval at Slitebrottet 2, the presence of the above-named Gotlandochitina species and Ancyrochitina cf. gutnica allows us to correlate the lower part of the Slitebrottet 2 section with the $C$. cingulata Biozone and the uppermost part of the studied $15 \mathrm{~m}$ interval with the E. lagena Biozone (see Nestor, 1994) which is probably continuing upwards.

According to Laufeld $(1974$, p. 33$)$, in the adjacent old marlstone quarry of Slitebrottet 1 (see Fig. 3), Gotlandochitina martinssoni and G. spinosa range throughout the sequence, except the topmost part - subunit "g" (7-16 m above sea level). The same Gotlandochitina species occur also in the topmost part of the E. lagena Biozone in the Ohesaare core (see Fig. 3). This indicates the span of the E. lagena Biozone also over the upper part of the Slitebrottet 2 section not studied by us and the lower part of the section at Slitebrottet 1 . The index species of the next, Conochitina pachycephala Biozone has not been recorded at 
Slitebrottet 1. In the Ohesaare core section, above the range of Gotlandochitina martinssoni and $G$. spinosa, remains a $90 \mathrm{~m}$ thick interval of the Jaagarahu Stage. It includes the upper part of the Jamaja Formation and the whole range of the Sõrve Formation, containing chitinozoans of the Conochitina subcyatha, C. cribrosa, and Sphaerochitina indecora biozones (Nestor, 1994).

The corresponding beds are totally lacking in the outcrop area of Saaremaa, where a considerable hiatus has been established between the Jaagarahu and Rootsiküla stages (Nestor \& Nestor, 1991). The above-mentioned chitinozoan species have never been found in the Gotland sequence either. This proves the presence of a similar stratigraphic break at the top of the Slite Beds supposed already earlier (Laufeld, 1974; Jeppsson et al., 1994).

\section{CONCLUSIONS}

1. According to the chitinozoan succession studied in the Vattenfallet and Nygårdsbecken localities, not any boundary between the subunits of the Högklint Beds corresponds exactly to the expressive chitinozoan boundary which coincides with the junction of the Mustjala and Ninase members in the sections of Saaremaa and is traceable also within the deep-water argillaceous marlstones of the Tõlla Beds. Obviously, the formation of the shoal-reef facies began somewhat earlier on Gotland.

2. The correlation of nodular limestones of the Slite Marl in the stratotypical sections of Slitebrottet 1 and 2 with predominantly argillaceous dolomitic marlstones of the Jamaja Formation of the Ohesaare core is not yet clear in details. However, the succession of chitinozoan species shows that the interval studied at Slitebrottet 2 corresponds to the uppermost part of the Cingulochitina cingulata Biozone and the lowermost part of the Eisenackitina lagena Biozone. The latter biozone probably ranges also through a certain part of the Slitebrottet 1 section. The beds, corresponding to the upper part of the Jamaja Formation and to the Sõrve Formation of the Jaagarahu Stage in the subsurface Ohesaare section, are probably missing in the outcrop area of western Gotland.

3. Chitinozoan-based correlation allows for more precise determination of some lithologic boundaries as well. The first appearance of Eisenackitina lagena at Slitebrottet 2 (Fig. 6) just above the base of the upper mesocyclite (39.6 m) enables us to correlate this level with an indistinct boundary of cyclites in the Ohesaare section at a depth of $273.6 \mathrm{~m}$ and the base of the lowermost mesocyclite in the Slitebrottet section $(46.7 \mathrm{~m})$ with the more clearly expressed boundary of cyclites in the Ohesaare section at a depth of $294.1 \mathrm{~m}$, which probably corresponds to the boundary of the Vilsandi and Maasi beds in northern Saaremaa. 
This study was carried out in cooperation with Björn Neuman from Bergen University, who guided us during eight days on Gotland. We are grateful to Lennart Jeppsson for good advice and for the permission to use his preliminary data (figure) on the Slitebrottet 2 section. We thank Dimitri Kaljo, Tõnu Meidla, and Heldur Nestor for useful comments and Kaie Ronk for drawings. The field work on Gotland Island was supported by the Swedish Royal Academy of Sciences and the Estonian Science Foundation (grant No. 1665), for which the authors are most grateful.

\section{REFERENCES}

Antoshkina, A. I., Lopushinskaya, T. V., Matukhin, R. G., Matukhina, V. G., Rasskazova, N. B., Patrunov, D. K., Pershina, A. I. \& Einasto, R. E. 1976. On the history of the Silurian basins of Siberian and East European platforms. Trudy SNIIGGIMS, 218, 24-40 (in Russian).

Einasto, R. 1986. Main stages of development and facies models of the East Baltic Silurian pericontinental basin. In Theory and Practice of Ecostratigraphy (Kaljo, D. \& Klaamann, E., eds.). Valgus, Tallinn, 37-54 (in Russian).

Einsele, G., Ricken, W. \& Seilacher, A. 1991. Cycles and events in stratigraphy - basic concepts and terms. In Cycles and Events in Stratigraphy (Einsele, G., Ricken, W. \& Seilacher, A., eds.). Springer-Verlag, Berlin, 1-19.

Jaanusson, V. 1979. Stratigraphical and environmental background. In Lower Wenlock Faunal and Floral Dynamics - Vattenfallet Section, Gotland (Jaanusson, V., Laufeld, S. \& Skoglund, R., eds.). Sver. Geol. Unders., 73, 3, 11-38.

Jeppsson, L., Viira, V. \& Männik, P. 1994. Silurian conodont-based correlation between Gotland (Sweden) and Saaremaa (Estonia). Geol. Mag., 131, 2, 201-218.

Johnson, M. E., Kaljo, D. \& Rong, J.-Y. 1991. Silurian eustasy. In The Murchison Symposium (Bassett, M. G., Lane, P. D. \& Edwards, D., eds.). Special Papers in Palaeontology, 44, 145-163.

Kaljo, D. (ed.). 1970. The Silurian of Estonia. Valgus, Tallinn (in Russian).

Kaljo, D., Nestor, H. \& Einasto, R. 1991. Aspects of Silurian carbonate platform sedimentation. In The Murchison Symposium (Bassett, M. G., Lane, P. D. \& Edwards, D., eds.). Special Papers in Palaeontology, 44, 205-224.

Laufeld, S. 1974. Silurian Chitinozoa from Gotland. Fossils and Strata, 5.

Laufeld, S. 1979. Chitinozoans. In Lower Wenlock Faunal and Floral Dynamics - Vattenfallet Section, Gotland (Jaanusson, V., Laufeld, S. \& Skoglund, R., eds.). Sver. Geol. Unders., 73, 3, 70-76.

Manten, A. A. 1971. Silurian Reefs of Gotland. Developments in Sedimentology, 13.

Nestor, H. 1990. Some aspects of lithology of the Ordovician and Silurian rocks. In Field Meeting Estonia 1990. An Excursion Guidebook (Kaljo, D. \& Nestor, H., eds.). Tallinn, 27-32.

Nestor, H. \& Einasto, R. 1977. Facies-sedimentary model of the Silurian Paleobaltic pericontinental basin. In Facies and Fauna of the Baltic Silurian (Kaljo, D, ed.). Tallinn, 89-121 (in Russian).

Nestor, V. 1982. Correlation of the East Baltic and Gotland Silurian by chitinozoans. In Ecostratigraphy of the East Baltic Silurian (Kaljo, D. \& Klaamann, E., eds.). Valgus, Tallinn, 89-96. 
Nestor, V. 1984. Zonal distribution of chitinozoans in the Wenlockian Jaani Stage of Estonia and the problem of its upper boundary. In Stratigraphy and Early Paleozoic Sediments of East Baltic (Männil, R. \& Mens, K., eds.). Tallinn, 119-127 (in Russian).

Nestor, V. 1990. Silurian chitinozoans. In Field Meeting Estonia 1990. An Excursion Guidebook (Kaljo, D. \& Nestor, H., eds.). Tallinn, 80-83.

Nestor, V. 1993. Chitinozoans at the Llandovery-Wenlock transition in the Jaagarahu core, Estonia. Proc. Estonian Acad. Sci. Geol., 42, 4, 167-175.

Nestor, V. 1994. Early Silurian Chitinozoans of Estonia and North Latvia. Academia, 4.

Nestor, V. \& Nestor, H. 1991. Dating of the Wenlock carbonate sequences in Estonia and stratigraphic breaks. Proc. Estonian Acad. Sci. Geol., 40, 2, 50-60.

Vail, P. R., Audemand, S. A., Bowman, S. A., Eisner, P. N. \& Perez-Cruz, C. 1991. The stratigraphic signatures of tectonics, eustasy and sedimentology - an overview. In Cycles and Events in Stratigraphy (Einsele, G., Ricken, W. \& Seilacher, A., eds.). SpringerVerlag, Berlin, 617-659.

\title{
MÕNE GOTLANDI WENLOCKI PALJANDI RÖÖBISTAMINE OHESAARE (SAAREMAA, EESTI) LÄBILÕIKEGA
}

\author{
Viiu NESTOR ja Rein EINASTO
}

Högklindi kihid Vattenfalleti ja Nygårdsbeckeni paljandis on esindatud Paleobalti basseini šelfi ja suletud šelfi ning madaliku setetega, kusjuures ükski Högklindi alajaotuste piiridest ei vasta kitinosoade alusel täpselt teravalt väljendunud Mustjala ja Ninase kihistiku vahelisele piirile Eesti läbilõigetes. Autorite uuritud karjääri Slitebrottet 2 alumises osas esinevad avašelfi muguljad lubjakivid koos paari terava katkestuspinnaga, mis tähistavad mikro- ja mesotsükliitide piire. Omavahel sarnane kitinosoade kooslus võimaldab rööbistada Slitebrotteti karjääri uuritud osa Jamaja kihistu alumise ja keskmise osaga Ohesaare läbilõikes, kus see vastab Cingulochitina cingulata biotsooni ülemisele poolele ja Eisenackitina lagena biotsooni alumisele poolele. Kitinosoade korrelatsiooni abil on võimalik rööbistada ka mesotsükliitide piire samades läbilõigetes.

\section{СОПОСТАВЛЕНИЕ НЕКОТОРЫХ РАЗРЕЗОВ ВЕНЛОКСКИХ ОТЛОЖЕНИЙ О-ВА ГОТЛАНД С РАЗРЕЗОМ СКВ. OХЕСАAРЕ НА О-ВЕ САAРЕМАА, ЭСТОНИЯ}

\section{Вийу НЕСТОР и Рейн ЭЙНАСТО}

Хёгклинтские слои в обнажениях Ваттенфаллет и Нюгярдсбекен представлены карбонатными отложениями открытого и отгороженного шельфа, а местами и чистыми биодетритовыми отложениями отмельной фациальной 
зоны Палеобалтийского бассейна. Ни одна из границ подразделений Хёгклинта не совпадает по хитинозоям с маркерной границей мустъялаской и ниназеской пачек яаниской свиты в эстонских разрезах. Изученные авторами слои комковатых известняков с двумя четкими сильнопиритизированными поверхностями перерыва (границы мезоциклитов) в нижней части карьера Слитеброттет 2 хорошо коррелируются по сообществам хитинозой с разрезом скв. Охесааре, составляющим верхнюю часть биозоны Cingulochitina cingulata и нижнюю часть биозоны Eisenackitina lagena, на уровне нижней и средней частей ямаяской свиты. Данная корреляция позволяет сопоставить и границы мезоциклитов в этих разрезах. 